Journalof BANKING \&

FINANCE

www.elsevier.com/locate/econbase

\title{
Emerging problems with the Basel Capital Accord: Regulatory capital arbitrage and related issues is
}

\author{
David Jones * \\ Division of Research and Statistics, Board of Governors of the Federal Reserve System, Washington, \\ DC 20551, USA
}

\begin{abstract}
In recent years, securitization and other financial innovations have provided unprecedented opportunities for banks to reduce substantially their regulatory capital requirements with little or no corresponding reduction in their overall economic risks a process termed "regulatory capital arbitrage". These methods are used routinely to lower the effective risk-based capital requirements against certain portfolios to levels well below the Basel Capital Accord's nominal 8\% total risk-based capital standard. This paper discusses the principal techniques used to undertake capital arbitrage and the difficulties faced by bank supervisors in attempting to deal with these activities under the current capital framework. (C) 2000 Elsevier Science B.V. All rights reserved.
\end{abstract}

JEL classification: G18; G21; G28

Keywords: Securitization; Capital regulation; Bank regulation.

\footnotetext{
The views expressed in this paper are those of the author, and do not necessarily reflect the views of the Federal Reserve System or other members of its staff.

*Tel.: +1-202-452-3888.

E-mail address: djones@frb.gov (D. Jones).
} 


\section{Introduction and overview}

Arithmetically, banks attempting to boost their risk-based capital (RBC) ratios under the 1988 Basel Capital Accord (the "Accord") have but two options for achieving that end: (a) increasing the measures of regulatory capital appearing in the numerators of these ratios (e.g., tier 1 or total capital), or (b) decreasing the regulatory measures of total risk appearing in the denominators (e.g., total risk-weighted assets). Available evidence suggests that in the short run, most banks have tended to react to capital pressures in the ways broadly envisioned by the framers of the Accord. That is, by increasing their capacity to absorb unexpected losses through increased earnings retentions or new capital issues, and by lowering their assumed risks through reductions in loans and other footings.

Quite apart from these "traditional" (on-balance sheet) adjustments, evidence also suggests that in some circumstances banks may attempt to boost reported capital ratios through purely "cosmetic" adjustments, which do little to enhance underlying safety and soundness. Broadly, such cosmetic adjustments involve artificially inflating the measures of capital appearing in the numerators of regulatory capital ratios, or artificially deflating the measures of total risk appearing in the denominators. Where permitted by applicable accounting standards or supervisory policies, examples of the former (termed "cosmetic capital adjustments") include devices such as gains trading or underprovisioning for loan loss reserves. Often such actions boost regulatory capital levels only temporarily, and may not correspond to any real increase in a bank's capacity to absorb future unexpected losses.

The second form of cosmetic adjustment exploits shortcomings in the measures of total risk appearing in the denominators of regulatory capital ratios. In recent years, securitization and other financial innovations have provided unprecedented opportunities for banks to reduce substantially their regulatory measures of risk, with little or no corresponding reduction in their overall economic risks - a process termed "regulatory capital arbitrage" (RCA). These methods are used routinely to lower the effective RBC requirements against certain portfolios to levels well below the Accord's nominal 8\% total RBC standard. Even with the same nominal capital standard in place across banks and over time, the avoidance of regulatory capital requirements through RCA constitutes an erosion of effective capital standards.

The consequences of RCA are several. Foremost, there is a greater likelihood that reported regulatory capital ratios could mask deteriorations in the true financial conditions of banks. Competitive inequities also may emerge to the extent that RCA is not equally accessible to all banks, possibly owing to economies of scale and scope, or international differences in accounting, supervisory, and legal regimes. Available evidence suggests that the volume of RCA activity is large and growing rapidly, especially among the largest banks. 
Moreover, with ongoing advances in securitization techniques, credit derivatives, and other financial innovations working to reduce the costs of RCA, these trends remain unabated. Absent measures to reduce incentives or opportunities for RCA, over time such developments could undermine the usefulness of formal capital requirements as prudential policy tools.

Ultimately, RCA is driven by large divergences that frequently arise between underlying economic risks and the notions and measures of risk embodied in regulatory capital ratios. As discussed below, such divergences create opportunities to unbundle and repackage a portfolio's risks in ways that can reduce dramatically the effective capital requirement per dollar of economic risk retained by a bank. Efforts to stem RCA without narrowing or eliminating these divergences - for example, by limiting banks' use of securitization and other risk unbundling technologies - would be counterproductive and perhaps untenable. In some circumstances, RCA is an important "safety-valve" that permits banks to compete effectively (with nonbanks) in low-risk businesses they would otherwise be forced to exit owing to unreasonably high regulatory capital requirements. Moreover, as evidenced through their widespread use by nonbanks, securitization and other risk unbundling technologies appear to provide genuine economic benefits to banks, quite apart from their role in RCA. Lastly, the same shortcomings giving rise to RCA under the Accord also distort bank behavior in other ways, such as discouraging the true hedging of economic risks.

The remainder of this paper examines RCA in greater detail. After outlining the economic factors motivating RCA, we review some of the most common RCA techniques and some evidence suggestive of the magnitude of these activities. We then discuss the prudential concerns raised by RCA and the difficult trade-offs faced by policy makers attempting to deal with these problems under the current Accord.

At the outset it should be noted that, to date, RCA has attracted scant academic attention. In part, the lack of published research no doubt reflects the scarcity of public data with which to undertake formal econometric analysis of this topic. It may also reflect the complexity of the underlying transactions. Regulatory capital arbitrage often involves the channeling of banking risks through so-called "special-purpose vehicles" (SPVs), which are entities created solely to unbundle and repackage risks in ways that elicit preferential treatments under applicable accounting standards; under corporate, tax, bankruptcy, and security laws; and under banking statutes and regulations. Although these structures facilitate assessing the riskiness of the Asset-Backed Securities (ABSs) issued by SPVs, invariably the risk implications for sponsoring banks are much less transparent. Yet a third factor limiting research is the torrid pace at which RCA techniques have been evolving, reflecting both ongoing financial innovation and complementary advances in computing and telecommunications. Due to the limited academic literature, the following 
discussion draws heavily from market sources of information, such as rating agencies, and from information collected by US regulators through on-site examinations.

\section{Factors motivating regulatory capital arbitrage}

The cost of equity is generally perceived to be much greater than the cost of debt, owing to tax considerations, asymmetric information, agency costs, and the bank safety net (e.g., direct access to government deposit insurance, the discount window, and the payments system). For this reason, when regulatory capital standards require banks to maintain equity cushions exceeding what they would otherwise choose based on market discipline alone, banks may view these standards as a form of regulatory taxation (Donahoo and Shaffer, 1991). As with other forms of taxation, regulatory taxes encourage banks to develop methods for serving customers that avoid or minimize these taxes. Several studies, using mainly pre-Accord data, report findings broadly consistent with the view that bank behavior is influenced by regulatory taxation, defined to encompass minimum capital requirements, reserve requirements and any deposit insurance premiums (Cumming, 1987; Baer and Pavel, 1988; Pavel and Phillis, 1987; Koppenhaver, 1989; Berger and Udell, 1993 and Jagtiani et al., 1995).

Many banks perceive that through RCA they can enhance shareholder value by replacing equity with debt in their capital structures. The "freed up" equity is then either returned to shareholders as increased dividends or share repurchases, or redeployed within the firm. The institutionalization of equity holdings in the hands of mutual funds and other professional portfolio managers appears to have increased pressures on banks to maximize equity values and to rationalize their equity retention policies. Heightened domestic and international competition in the financial services industry probably has reinforced incentives for banks to keep their production costs, including the overall costof-capital (debt + equity), as low as possible.

Regulatory capital arbitrage - like traditional tax arbitrage - represents a bank's willingness to incur various "structuring costs" in order to reduce the regulatory tax consequences of formal capital requirements. ${ }^{1} \mathrm{~A}$ bank's decision about whether to engage in RCA, and on what scale, reflects a cost-benefit analysis in which the expected structuring costs are weighed against both the expected reduction in the bank's overall funding costs and any other benefits

\footnotetext{
${ }^{1}$ A related idea, advanced by Giddy (1985), is that in response to the imposition of regulatory capital requirements for credit risk, banks can be expected to expand those activities having relatively large concentrations of non-credit risks, such as interest rate and operating risks.
} 
(Pennacchi, 1988; Cumming, 1987; James, 1988; Passmore, 1992; Chhikara and Hanson, 1993). For a given perceived differential between the cost of equity and the cost of debt financing, incentives to undertake RCA, therefore, are related negatively to the associated structuring costs, and positively to the extent to which RCA permits debt to be substituted for equity (i.e., the amount of "freed up" regulatory capital).

\subsection{Structuring costs}

As suggested in Merton (1995), the basic insight behind RCA follows from the observation that, when capital standards are not based on any consistent economic soundness standard (e.g., probability of insolvency), through securitization and other techniques it is often possible to restructure portfolios to have basically similar risks, but much lower regulatory capital requirements. Importantly, as emphasized by Cumming (1987), the process of unbundling and repackaging risks incurs costs, which are a key determinant of a bank's willingness to engage in RCA. The lower these structuring costs, the greater the incentives to undertake RCA, other things the same.

Broadly, structuring costs may be external or internal. The former include all out-of-pocket expenses to third-parties (e.g., fees to underwriters, lawyers, credit rating agencies, etc.) as well as any increase in the bank's net interest costs associated with the use of off-balance sheet funding sources, such as ABSs, in lieu of on-balance sheet funding, such as deposits. ${ }^{2}$ Examples of internal structuring costs include any required modifications to loan administration and management information systems to support securitizaions.

There appear to be no published studies tabulating structuring costs for different types of RCA. Anecdotal evidence suggests that such costs display substantial economies of scale, and depend on many factors including the nature and riskiness of the underlying assets, legal complexities and uncertainties, and investors' familiarity with transactions of that type. Ongoing financial innovations, technological advances, and increased competition in the financial services sector have been working to reduce structuring costs over time.

\subsection{Amount of "freed up" regulatory capital}

To maintain their credit ratings, preserve operating flexibility, and to qualify for the "well-capitalized" prompt corrective action category, large US banks

\footnotetext{
${ }^{2}$ For banks having high investment-grade credit ratings, securitizations often imply weighted average yields on the ABSs (inclusive of fees to third-party credit enchanters) that exceed yields on the banks' directly-issued debt.
} 
normally establish internal tier 1 and total $\mathrm{RBC}$ ratio targets substantially above the nominal 4\% and $8 \%$ regulatory minimum set by the Accord. In essence, RCA enables banks to achieve internal capital ratio targets with lower amounts of tier 1 capital, thereby reducing a bank's effective (tier 1) regulatory capital requirement. The amount of regulatory capital that can be freed up by RCA (or equivalently, the extent to which a bank can reduce its effective regulatory capital requirement) will depend on the specific RCA techniques employed. Below, we discuss several of the most common RCA techniques.

\section{Regulatory capital arbitrage in practice}

In general, RCA exploits differences between a portfolio's true economic risks and the notions and measurements of risk implicit in regulatory capital standards. Using a series of examples that progress from very simple to more complex structures, we shall describe several of the most common RCA techniques employed by Canadian, European, Japanese and US banks. This discussion is intended to be illustrative, rather than exhaustive. Indeed, the specific techniques encountered in practice continue to evolve in response to financial innovations, changes in accounting standards, and other factors.

To set the stage, consider a bank whose balance sheet consists of US\$100 in loans, US\$95 in deposits, and US\$5 in equity. Thus, the bank's implied leverage ratio is $5 \%$. Note that the bank's risk profile would be fundamentally unchanged if it were to sell US\$50 of these loans to a third-party investor, while providing credit enhancement through issuance of a US\$50 standby letter of credit or other off-balance sheet financial guarantee. Nevertheless, this simple form of RCA would double the bank's reported leverage ratio, to $10 \%$.

Of course, the Accord precludes such straightforward RCA by imposing $\mathrm{RBC}$ requirements on financial guarantees. ${ }^{3}$ When a financial guarantee enhances assets that the bank itself has sold, the guarantee is termed "recourse", which in the US usually incurs a "dollar-for-dollar" total RBC requirement equal to amount of the guarantee, defined as the bank's Maximum Potential Credit Loss (MPCL) under the arrangement. Alternatively, if the enhanced assets have not previously been owned by the bank, the financial guarantee is termed a "direct credit substitute". In this case, the associated RBC requirement would equal $8 \%$ of the amount of the guarantee (i.e., equivalent to assigning a $100 \%$ risk-weight to the amount of the guarantee). While the Accord's treatment of financial guarantees prevents a bank from lowering its effective

\footnotetext{
${ }^{3}$ For RBC purposes, a financial guarantee is any credit enhancement backing financial assets or off-balance sheet items that, if held by a bank, would require capital under the Accord.
} 
Table 1

Risk-based capital requirements for selected banking book instruments, percent of maximum possible credit loss

\begin{tabular}{ll}
\hline Type of instrument & Effective total RBC requirement \\
\hline Whole loans & \\
$\quad$ Uncollateralized/unguaranteed & 8.0 \\
Collateralized/guaranteed & \\
$\quad$ OECD government & 0.0 \\
$\quad$ OECD bank/securities dealer & 1.6 \\
$\quad$ Other collateral/guarantee & 8.0 \\
Loan commitments & 0.0 \\
$\quad$ One-year or less & 4.0 \\
More than one-year & 0.0 \\
Written put option (loans or bonds) & \\
Financial guarantees (includes credit derivatives) & 8.0 \\
$\quad$ Direct credit substitute & 100.0 \\
Recourse &
\end{tabular}

$\mathrm{RBC}$ requirement merely by selling loans with $100 \%$ recourse, the creative use of financial guarantees is the basis for much of the RCA observed in practice.

Under the Accord, inconsistencies among the RBC treatments of different assets can result in widely disparate $\mathrm{RBC}$ requirements against portfolios with largely similar risks. Table 1 illustrates the range of effective $\mathrm{RBC}$ requirements applicable to selected credit instruments held in the banking book. The entries in the exhibit refer to credit or reference assets for which the underlying obligor's debt, on a stand-alone basis, would receive a $100 \%$ risk-weight. The applicable RBC treatment for a particular asset depends both on the type of financial instrument and on the MPCL the bank could experience on that instrument. ${ }^{4}$ Recourse incurs the largest effective RBC requirement (dollar-fordollar), while short-term loan commitments and written put options on bonds or loans incur the smallest requirements $(0 \%)$.

Regulatory capital arbitrage normally involves unbundling and repackaging risks so that, as measured for $\mathrm{RBC}$ purposes, a disproportionate amount of the portfolio's true underlying credit risk is treated as lower risk-weighted assets, or as having been sold to third-party investors. Currently, most RCA revolves around the following three guiding principles:

Principle 1 (Concentrate credit risk and cherry pick). Restructure positions so as to "concentrate" the bulk of the underlying credit risks into instruments having a combined MPCL much smaller than that for the original portfolio.

\footnotetext{
${ }^{4}$ For traditional credit instruments, such as plain-vanilla loans, the MPCL usually equals the underlying notional exposure. For leveraged derivative products, the MPCL may exceed the notional amount of underlying reference asset.
} 
By implication, the remaining instruments will entail relatively low levels of credit risk, but a relatively large portion of the portfolio's MPCL. Sell these low-risk instruments to investors (a form of "cherry picking").

Principle 2 (Remote-origination). Where possible, structure transactions to ensure that any retained risks under Principle 1 are treated as direct credit substitutes (subject to an $8 \%$ effective capital requirement), rather than as recourse (subject to a dollar-for-dollar capital requirement). In general, this requires that the sponsoring bank never formally own the underlying assets ("remote-origination").

Principle 3 (Indirect credit enhancements). Where possible, convert credit exposures into contractual arrangements that, while providing some investor protection, are not recognized as financial guarantees. Such "indirect credit enhancements" typically incur no RBC requirement. Below, each of these principles is discussed in turn. Numerical examples illustrating each principle are presented in Appendix A.

\subsection{Principle 1: Concentrate credit risk and cherry pick}

This principle is perhaps the most common of all RCA techniques. It involves unbundling and repackaging a loan pool's cash flows through securitization or other means (see below) so that the vast bulk of the credit risk is "concentrated" within financial instruments having a much smaller MPCL than the original portfolio. Often this can be accomplished so that the remaining cash flow claims - bearing relatively little credit risk - receive investment-grade credit ratings, making it possible to sell these low-risk claims to third-party investors at narrow credit risk spreads. Thus, following the transaction the bank assumes much the same credit risk as before, but in the form of financial instruments having a much smaller MPCL footprint. The concentrated credit risk positions retained by the bank would be normally be considered a financial guarantee and be treated as recourse, subject to a dollarfor-dollar RBC requirement. Nevertheless, provided the recourse is less than $8 \%$ of the pool, this technique generally leads to lower capital requirements against the recourse than against the original asset pool, even though little, if any, credit risk may be transferred to investors.

It is useful to note that cherry picking alone can reduce a bank's effective $\mathrm{RBC}$ requirement per dollar of assumed risks. For example, consider the strategy of reducing a portfolio's MPCL by selling off the highest-quality whole loans. ${ }^{5}$ Through such cherry picking, the bank's RBC requirement would

\footnotetext{
${ }^{5}$ Below, we assume for simplicity that all loans are subject to a $100 \%$ risk-weight.
} 
decline in proportion to the reduction in loans, even though the actual decline in the bank's overall credit risk would be much less, since the retained loans have below-average credit quality.

Securitization is often a more cost-effective approach to cherry picking than whole loan sales. In its most basic form, securitization is a device for separating the financing from the origination and servicing of whole loans. Typically, a sponsoring bank forms a "special-purpose vehicle" (SPV) to acquire loans from the sponsor or other financial institutions. To finance these purchases, the SPV issues to investors ABSs collateralized by the underlying loan pool. For certain asset types, the market discipline imposed by the rating agencies and the ability to tailor ABSs to the needs of specific investors allows banks to realize greater returns through securitizations of these assets than through whole loan sales.

In many circumstances, the credit risk spreads demanded by investors to acquire whole loans or ABSs without credit enhancements from the sponsoring bank would render the cost of such transactions prohibitive. Securitization with retained recourse, where credit risk is "concentrated" before cherry picking, is often a less costly method of RCA. The basic approach involves creating multiple tranches of ABSs from a loan pool, where the claims of each lower tranche are subordinated to the claims of more senior tranches. In effect, each subordinated tranche acts as a credit enhancement for all higher level tranches. The most subordinated tranche, therefore, represents a highly concentrated credit risk position.

Through subordination, the vast bulk of a loan pool's credit risk frequently can be concentrated into a subordinated tranche whose MPCL is but a small fraction of the MPCL of the underlying pool. As illustrated in Appendix A, provided the MPCL of this tranche is less than $8 \%$ of the pool, a bank can generally increase its RBC ratios by retaining this recourse position and selling more senior tranches to investors - despite incurring an effective $100 \% \mathrm{RBC}$ charge against the subordinated recourse position. In securitizations of consumer and higher-quality commercial loans, retained recourse amounting to less than $4 \%$ of the underlying loan pool may be sufficient to achieve investment-grade ratings on the ABSs sold to investors. Although these ratings usually imply that very little credit risk is actually transferred to investors, such securitizations nevertheless can reduce the bank's RBC requirement dramatically (in this example by more than half) relative to its requirement had the whole loans remained on its balance sheet.

As a general matter, RCA through securitization with retained recourse is most cost-effective when the underlying loan pool is of sufficiently high quality that most of the credit risk can be concentrated into a subordinated tranche whose MPCL is well below $8 \%$ of the pool. The practical consequence is that, for purposes of RCA, the types of assets selected for securitization by banks tend to be above-average along a number of dimensions. First, securitized asset 
types tend to exhibit more predictable default rates and expected loss rates in the event of default. Second, securitized loan pools normally are very highly diversified. The pools underlying most collateralized loan obligations (CLOs), for example, must conform to stringent diversification standards established by the rating agencies that sharply limit each pool's risk concentrations with respect to individual firms, geographic regions, and industrial sectors. As a consequence, a bank's on-balance sheet portfolio may display less diversification than the loans it has securitized.

It is important to emphasize that while RCA is one factor encouraging certain forms of securitization by banks, it is by no means the only factor. Recent studies by Carlstrom and Samolyk (1995); Gorton and Pennacchi (1995) and DeMarzo and Duffie (1999) provide alternative explanations for the growth in securitization activity based on the notion that certain institutions have a natural comparative advantage in originating, but not necessarily holding, illiquid assets. Owing to asymmetric information and moral hazard problems, they suggest that securitization may be a more efficient funding mechanism than whole loan sales.

\subsection{Principle 2: Remote-origination}

More sophisticated methods of RCA can reduce the amount of equity capital that is freed up through securitization programs. One increasingly common technique involves altering the structure of the securitization program so that any financial guarantees provided by the sponsoring bank are treated as direct credit substitutes, rather than recourse, thereby reducing the bank's total RBC requirement from $100 \%$ to only $8 \%$ of the guarantee's MPCL. This is achieved by having the SPV, rather than the bank itself, originate the underlying securitized assets - a process termed "remote-origination". Since the securitized assets will not have been owned or sold by the bank, credit enhancement provided by the bank to the ABS investors is not formally "recourse".

Virtually all asset-backed commercial paper programs (ABCPs) are structured as remote-origination vehicles. Under these programs, a bank establishes an SPV to which it refers customers satisfying underwriting criteria confirmed by the credit rating agencies. The SPV advances funds to borrowers through direct loans or through asset purchase agreements under which the SPV purchases trade receivables or other assets. To fund its asset purchases, the SPV issues highly rated commercial paper to investors, while the sponsoring bank provides credit enhancements to the ABCP investors in the form of "credit enhancement facilities" whose MPCL is generally less than $20 \%$ of the SPV's commercial paper issuance. Because the SPV's assets are remotely originated, the sponsoring bank's credit enhancements are treated as direct credit substitutes, and incur a $\mathrm{RBC}$ requirement equal to $8 \%$ of their MPCL. Overall, this 
structure results in an effective $\mathrm{RBC}$ requirement against the underlying assets of less than $1.6 \%(8 \% \times 0.20)$. In contrast, had the sponsoring bank originated these assets directly, its effective RBC requirement would have equaled $8 \%$.

\subsection{Principle 3: Indirect credit enhancements}

The above examples have presumed that any credit enhancements provided to $\mathrm{ABS}$ investors by a sponsoring bank are treated as a financial guarantee for RBC purposes. Depending on whether or not the bank itself originated the assets, such "direct" credit enhancements would be treated either as recourse or as a direct credit substitute. In some cases, however, it is possible for a sponsoring bank to structure credit enhancements in ways not formally recognized as financial guarantees. When this is possible, rating agencies may be willing to accept such "indirect" credit enhancements in lieu of direct credit enhancements, thereby reducing even further the bank's RBC requirement and increasing the amount of equity capital freed up by the transaction.

Indirect credit enhancements have features that make it difficult to place the instrument clearly within one of the Accord's positive risk-weight categories. When an instrument falls into such a "grey zone", the appropriate banking regulator must interpret the Accord in the manner they believe is most appropriate. To date, indirect credit enhancements have tended to be of two broad types: (a) items that, while providing some protection to investors, have been judged to exhibit credit risk most closely analogous to instruments assigned zero risk-weights by the Accord, such as short-term loan commitments and written put options; or (b) items that expose the bank to potential credit losses only under specific operating scenarios that bank management - at least in theory - has discretion to avoid. Each of these types is discussed below.

A. Low-risk interpretations. Typically, when an item falls within a grey zone, the appropriate banking regulator is required to place the item in either the $100 \%$ or the $0 \%$ risk-weight categories, even when some blended weighting might be more appropriate. In most circumstances, regulators have tended to apply fairly stringent standards, namely, that the item contain only di minimus credit risk comparable to other instruments already assigned zero risk-weights. In some instances, subsequent to such a determination market practices can evolve to where an item that previously satisfied this standard assumes a riskier profile over time.

So-called "structured liquidity facilities" associated with certain ABCP programs illustrate such a progression. As noted above, ABCP programs typically fund advances to borrowers by issuing highly-rated commercial paper to third-party investors. To achieve these high credit ratings, the bank sponsor normally is required by rating agencies to provide a combination of direct credit enhancements and backup liquidity facilities to the SPV so that, in total, 
they equal the amount of commercial paper outstanding. The direct credit enhancement often takes the form of either a standby letter of credit or a subordinated investment in the SPV (treated as a direct credit substitute), while the liquidity facility might be structured as a one-year loan commitment.

When the current RBC treatment of liquidity facilities was originally formulated, draw-downs under backup liquidity facilities generally were protected by credit enhancement facilities. These credit enhancement facilities, in turn, were sized to cover nearly all of the credit risk assumed by the SPV. While the liquidity facilities technically entailed some credit risk, as do all commitments, and could have been categorized as direct credit substitutes, the actual credit risk was judged to be negligible. Thus, the facilities were assigned $0 \%$ riskweights, the same as any other short-term commitment.

Currently, however, a number of ABCP programs sponsored by non-US banks provide credit enhancements entirely through their liquidity facilities (so-called "structured liquidity facilities") (Picer and Dierdorff, 1997). Structured liquidity facilities generally take the form of one-year loan commitments where draw-downs are subordinated to the commercial paper investors, or put options that permit the SPV to sell assets to the sponsoring bank at prices possibly exceeding their fair market values. Under some regulatory interpretations, these structured liquidity facilities incur no RBC requirement.

B. Operating risk interpretations. This form of indirect credit enhancement has become quite common in securitizations involving draw-downs under revolving credit facilities, which includes virtually all credit card programs and many CLOs. Draw-downs under revolving facilities tend to be repaid relatively quickly, often within a year, while many investors tend to prefer ABSs having maturities considerably longer (e.g., three to ten years). Sponsoring banks have resolved this conflict by adopting "master trust" arrangements whereby (a) the bank "designates" certain lines of credit to the SPV, and (b) all draw-downs under these designated lines are required to be "sold" to the SPV. The SPV, in turn, funds these purchases by issuing ABSs to investors ("the investors' interest") and a para passu "seller's interest" to the sponsoring bank. Since the average maturity of the investors' interest typically exceeds that of the underlying loans, over time the seller's interest will fluctuate as draw-downs under the designated accounts move up and down. To ensure there is always sufficient collateral within the SPV to cover the ABSs with some cushion, rating agencies generally require that the seller's interest remain above some pre-specified minimum level (e.g., for credit card programs, around $7 \%$ of the investors' interest).

The nature of these securitization programs generally implies that over time the sponsoring bank must periodically convey new draw-downs to the SPV. The sponsoring bank's ongoing operational responsibility for originating new draw-downs provides the basis for certain indirect credit enhancements. In effect, these indirect enhancements take the form of contractual provisions that 
penalize the sponsoring bank in the event that it fails to generate sufficient high-quality loans to maintain the average quality of the securitized loan pool above some minimum standard. These penalties generally include (a) "early amortization triggers" designed to force a wind-down of the securitization program (i.e., rapid repayment of principal to investors); and (b) "fast-payout" provisions which, in the event of early amortization, require that a portion of the seller's share of principal payments may be subordinated to ABS investors.

To date, early amortization and fast-payout provisions generally have not been treated as financial guarantees for RBC purpose, and so have incurred no capital requirements under the Accord. The underlying rationale is two-fold. First, while such features provide some credit protection to ABS investors, the risk of loss to the sponsoring bank is viewed as slight (owing to the generally high quality of the underlying loans). Second, this risk has been interpreted as primarily operating risk, rather than credit risk, since the bank generally can avoid any penalties provided it meets its contractual obligation to provide the SPV with sufficient high-quality loans to avoid an early amortization. ${ }^{6}$ That is, for RBC purposes, the indirect credit enhancement is deemed to have transformed credit risk into operating risk, which is not subject to formal regulatory capital requirements under the Accord. ${ }^{7}$

\section{Extent of regulatory capital arbitrage}

For most banking organizations, neither public financial reports nor regulatory reports disclose sufficient information to measure the full extent of a bank's RCA activities. Even the full scope of a bank's securitization activities, and their implications for the institutions overall risks, can be difficult to assess.

To provide some gauge of the potential scale of RCA activity by banks, Federal Reserve staff have estimated the outstanding (non-mortgage related) ABSs and ABCP issued through programs sponsored by the 10 largest US

\footnotetext{
${ }^{6}$ In the context of "fast-pay" provisions, the sponsoring bank can avoid having any of its share of principal subordinated to ABS investors by refusing to permit draw-downs under the designated accounts in the event an early amortization is triggered. However, such an action may not be feasible if the underlying revolvers are committed facilities.

${ }^{7}$ Whether operating risk or credit risk in nature, concerns about triggering an early amortization can place sponsoring banks under considerable pressure to financially support ailing SPVs. Not only would an early amortization result in significant reputational damage, but as principal was repaid to ABS investors, the bank would likely be forced to replace this off-balance sheet funding with higher-cost sources. To avoid such costs, those few banks that have experienced problems with their SPVs invariably have responded by providing "voluntary" financial support to ABS investors. In certain situations, such voluntary support is deemed to constitute "implicit recourse", which can result in all the securitized assets of the supported SPV being treated as on-balance sheet assets of the sponsoring bank for RBC purposes.
} 
bank holding companies. ${ }^{8}$ Even excluding mortgage securitizations, these estimates reveal that the securitization activities of these companies loom large in relation to their on-balance sheet exposures. As of March 1998, outstanding non-mortgage $\mathrm{ABSs}$ and $\mathrm{ABCP}$ issuance through securitization programs sponsored by these institutions exceeded US\$200 billion, or more than $25 \%$ of the institutions' total risk-weighted loans. For several institutions, combined issuance of $\mathrm{ABSs}$ and $\mathrm{ABCP}$ approached $50 \%$ of their total risk-weighted loans. Although similar data are not available for non-US banks, market reports suggest that significant amounts of RCA-related securitizations have been undertaken by some Canadian, European and Japanese banks - particularly through CLOs and bank-sponsored ABCP programs.

Looking ahead, recent innovations in credit derivatives and the design of CLOs, together with additional capital arbitrage opportunities opened up by the Accord's 1997 Market Risk Amendment, are widely believed to afford large, sophisticated banks expanded opportunities for still further RCA. An important development stimulating growth in CLOs has been structural innovations that now permit banks to unbundle the credit risks of their loan portfolios while preserving valuable "customer relationships". Cumming (1987) suggests that bankers' concerns about undermining long-term customer relationships may have been one factor limiting the early securitization of business loans. Over the past two years, however, innovative uses of loan participations, credit risk derivatives, and legal structures originally developed for credit card securitizations now permit banks to transfer the credit risk of business loans to SPVs without having to divulge the names of the underlying customers either to investors or to the customers themselves.

Perhaps the greatest unknown in attempting to anticipate future trends in RCA relates to the potential implications of the 1997 Market Risk Amendment. This Amendment potentially creates additional capital arbitrage opportunities by permitting banks to use their Value-at-Risk (VaR) models for calculating RBC requirements against specific risks within their trading portfolios. Under this Amendment, a bank can potentially reduce its effective RBC requirement by shifting credit risks from its banking book to its trading account, if accounting principles permit.

Innovations in credit derivatives also may spur additional RCA. Some financial institutions are now marketing credit derivative products that, from a regulatory capital perspective, create "synthetic securitizations" that have much lower structuring costs than traditional securitizations. In such a transaction, a money-center bank or a securities firm might sell credit protection to a

\footnotetext{
${ }^{8}$ Most sales of commercial and residential mortgages by banks to securitization programs do not involve the provision of recourse by the selling banks; the estimates in the text include bank securitizations of home equity lines.
} 
regional bank (via credit derivatives) whereby the guarantor promises to cover all losses above a certain amount against a specified pool of loans. From the perspective of the beneficiary bank, this type of transaction is quite similar (though not identical) to a securitization transaction with recourse. These products have the potential to dramatically alter the economics of RCA, making RCA more cost-effective and more accessible to a much broader range of banks than in the past.

\section{Regulatory concerns}

Regulatory capital arbitrage raises a number of important policy concerns. Such activities tend to erode regulatory capital standards, and could impair regulatory discipline that is needed to limit systemic risk within the banking system and moral hazard associated with the bank safety net. At this point in time, the key issue probably is not that too little regulatory capital is being required against banks' retained risks in securitization programs. Since the underlying securitized assets tend to be of relatively high quality, a strong case can be made that the low capital requirements against these retained risks actually may be appropriate. Rather, a more serious concern is that by encouraging banks to securitize their highest quality assets ("cherry-picking"), RCA may tend to reduce the average credit quality of the remaining (unsecuritized) assets in the banking book to the point where the $8 \%$ total RBC standard is no longer sufficient and reported $\mathrm{RBC}$ ratios may misrepresent a bank's true financial condition.

Compounding this challenge is a lack of alternative supervisory tools (not based upon regulatory capital ratio measures) with which to assess bank capital adequacy. Thus, RCA runs some risk of masking potential weaknesses at banks and delaying prompt corrective actions. Distortions to reported regulatory capital ratios also may compromise market discipline, since these ratios are a key source of public information used by counterparties, investors, and other market participants when evaluating the conditions of banks.

Despite the worrisome safety and soundness concerns raised by RCA, options for addressing these issues within the current RBC framework are limited. As emphasized above, ultimately RCA stems from large discrepancies between the true economic risks of assets and the regulatory measures of risk embodied within the Accord. Unless these economic and regulatory measures of risk are brought into closer alignment, the underlying factors driving RCA are likely to remain unabated. Without addressing these underlying factors, supervisors may have little practical scope for limiting RCA other than by, in effect, imposing more or less arbitrary restrictions on banks' use of risk unbundling and repackaging technologies, including securitization and credit derivatives.

Such an approach, however, would be counterproductive (and politically unacceptable). Against the backdrop of regulatory capital requirements that 
are often quite arbitrary, in some circumstances RCA actually may improve a bank's financial condition and the overall efficiency of the financial system. Indeed, RCA is widely perceived as a "safety valve" for mitigating the adverse effects of regulatory capital requirements that exceed levels commensurate with an activity's underlying economic risks. Absent such arbitrage, an excessive nominal capital requirement could preclude a bank from undertaking low-risk activities that, while highly profitable on a risk-adjusted basis, yielded insufficient rates of return on the regulatory capital needed to support the business. By reducing banks' effective capital requirements against such activities to levels more consistent with the underlying economic risks, RCA may permit banks to compete efficiently in relatively safe businesses they would otherwise be forced to abandon.

Moreover, as evidenced by the observation that many non-banking firms make extensive use of securitization, RCA is not always the sole reason why banks undertake securitization transactions. Increased economies of scale, reduced costs of debt financing, and better diversification of funding sources are often cited as additional benefits to individual banks. More broadly, from the perspective of the economy as a whole, financial innovation and the "unbundling" of credit risks is widely believed to have contributed to the closer integration of domestic credit markets, improved interest rate and credit risk management tools, and increased competition in the financial services industry.

In assessing the challenges posed by RCA, it is also important to note that fundamentally the same shortcomings in the Accord giving rise to RCA also distort bank behavior in other dimensions which may equally troubling. As noted in a recent monograph by the International Swap Dealers Association (1998), the current Accord frequently discourages the true hedging of portfolio credit risks by banks, and sometimes penalizes such hedging with additional capital requirements. This reflects the very limited differentiation of credit risks under the Accord - including no recognition of diversification or the term structure of credit risk, and only partial recognition of collateral protection and the completely separate RBC treatments of banking book credit risk, trading book specific risk, and counterparty risk, which preclude offsetting long credit risk positions of one risk type against short positions in another. Attempts by regulators to restrain RCA, per se, without addressing these more fundamental shortcomings would do little to encourage more effective hedging of true economic risks by banks.

\section{Concluding remarks}

The preceding discussion has highlighted the challenges to regulators posed by ongoing financial innovation and incentives within the current RBC framework for banks to undertake RCA. Such arbitrage distorts regulatory 
capital ratio measures and silently erodes prudential capital standards - even though nominal capital requirements may remain constant, RCA lowers effective capital requirements over time in ways that are difficult to quantify given available supervisory tools. While securitization has been the classic mode for conducting RCA, recent financial innovations and the 1997 Market Risk Amendment raise the prospect that such arbitrage may expand dramatically in the coming years. Clearly, these developments need to be monitored closely. In addition, they highlight the importance of seeking ways to more closely align regulatory measures of risk with a bank's true economic risks. Absent greater convergence, regulatory capital standards seem destined to become increasingly distorted by financial innovation and improved methods of RCA - at least for those large, sophisticated banks having the resources to exploit such opportunities.

\section{Acknowledgements}

I am grateful for many discussions with, and useful comments from, Tom Boemio, Edward Ettin, Beverly Hirtle, Myron Kwast and John Mingo. Of course, I alone am responsible for errors or omissions.

\section{Appendix A. Regulatory capital arbitrage: Examples}

\section{A.1. Benchmark scenario: On-balance sheet loans}

To contrast the implications of various forms of RCA, we shall compare their regulatory capital implications to the benchmark scenario shown in Fig. 1, where all loans are held directly on the balance sheet. In this scenario, the credit risk portfolio is assumed to consist of US\$200 in gross loans, which are funded with US\$176 in deposits and US\$22 in equity capital. The loan loss reserve is assumed to equal the portfolio's expected credit loss. Ignoring tax effects, the bank's tier 1 and total RBC ratios would equal $11.0 \%$, and $12.0 \%$, respectively.

\section{A.2. Review of securitization without retained risks}

Fig. 2 assumes the above bank securitizes US\$40 of loans from its balance sheet by selling the assets without recourse (at par) to a bankruptcy-remote SPV. The SPV, in turn, funds this purchase by issuing US $\$ 40$ of ABSs to thirdparty investors. Relative to the benchmark scenario, this securitization without retained risks results in the bank transferring all the credit risk of the sec- 
uritized loans to investors. Commensurate with this risk reduction, the bank's total risk-weighted assets are reduced, increasing its tier 1 and total $\mathrm{RBC}$ ratios to $13.8 \%$ and $15.0 \% .9$

\section{A.3. Securitization with recourse}

Fig. 3 illustrates RCA in which a bank securitizes US\$42 of on-balance sheet term-loans, which support issuance of US\$40 in ABSs by the SPV. Unlike the preceding example, however, in this case the bank seeks to improve the credit ratings on the ABSs by providing credit enhancement to the investors. In practice, such credit enhancements can take many forms. For example, typically the SPV would be structured so that contractual principal and interest payments on the securitized loans exceed the expected costs of administering the SPV and the contractual interest on the ABSs. So long as principal and interest payments on the securitized loans are sufficient to cover these costs, any excess cash flow of the SPV (termed "excess servicing") would be returned to the sponsoring bank. However, if cash inflows to the SPV are insufficient to cover its costs, nothing would be paid to the bank. Thus, a positive expected level of excess servicing provides a form of credit enhancement to the ABS investors - functioning much like an equity position in the SPV. ${ }^{10}$

In addition to subordinating any excess servicing to ABS investors, banks often provide direct credit enhancements to ABS investors in the form of standby letters of credit or the acquisition of subordinated interests in the SPV. The amount of direct credit enhancement required by the rating agencies will tend to increase with the desired credit rating on the ABSs, and will tend to decrease with the credit quality of the underlying securitized loans. Fig. 3 assumes this direct credit enhancement takes the form of a US\$2 subordinated loan to the SPV. In practice, credit enhancements are often structured so that the ABSs receive relatively high investment-grade ratings (often AA/AAA). Often it can be inferred from such ratings that very little, if any, credit risk is actually transferred from the bank to ABS investors in these transactions.

For RBC purposes, the bank's loan to the SPV would be treated as recourse, and subject to a $100 \% \mathrm{RBC}$ requirement. Even so, despite transferring little

\footnotetext{
${ }^{9}$ This example assumes proceeds from the sale of ABSs are used to reduce the bank's outstanding deposit liabilities. For simplicity, the exhibit abstracts from any change in reserves at either the bank or SPV.

${ }^{10}$ Typically, the fair value of this excess servicing would be recorded as an asset on the bank's balance sheet, and would be treated as recourse (subject to a 100\% capital charge) for RBC purposes. Since the value of excess servicing tends to be very small in relation to the overall size of securitization transactions undertaken by major banks, for simplicity the GAAP accounting treatment of excess servicing is ignored in the examples below.
} 
Bank Balance Sheet

\begin{tabular}{lr|lr}
\hline Loans & 200.00 & Deposits & 176.00 \\
less Reserves & $(2.00)$ & Equity & 22.00 \\
Total Assets & 198.00 & &
\end{tabular}

$\begin{array}{llr}\text { Total RWA } & = & 200.00 \\ \text { Tier1 Capital } & = & 22.00 \\ \text { Total Capital } & = & 24.00 \\ \text { Tier 1 RBC ratio } & = & 11 \% \\ \text { Total RBC ratio } & = & 12 \%\end{array}$

Fig. 1. Benchmark scenario: On-balance sheet loans.

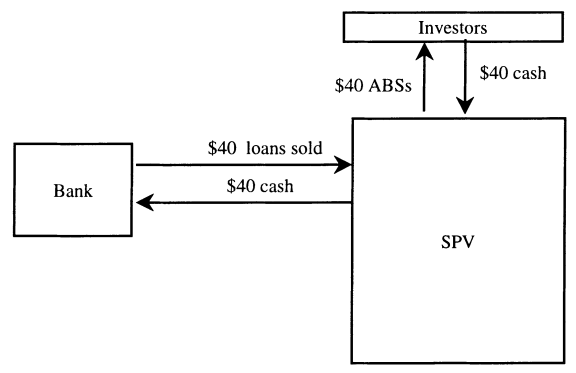

\begin{tabular}{ll|ll}
\multicolumn{4}{c}{ SPV } \\
\hline Loans & 40.00 & ABSs & 40.00
\end{tabular}

\begin{tabular}{lr|lr}
\multicolumn{4}{c}{ Bank } \\
\hline Loans & 160.00 & Deposits & 136.00 \\
less Reserves & $(2.00)$ & Equity & 22.00 \\
\hline Total Assets & 158.00 & &
\end{tabular}

$\begin{array}{llr}\text { Total RWA } & =160.00 \\ \text { Tier1 capital } & =22.00 \\ \text { Total capital } & =24.00 \\ \text { Tier } 1 \text { RBC ratio } & =13.8 \% \\ \text { Total RBC ratio } & =15.0 \%\end{array}$

Fig. 2. Securitization without retained risks. 


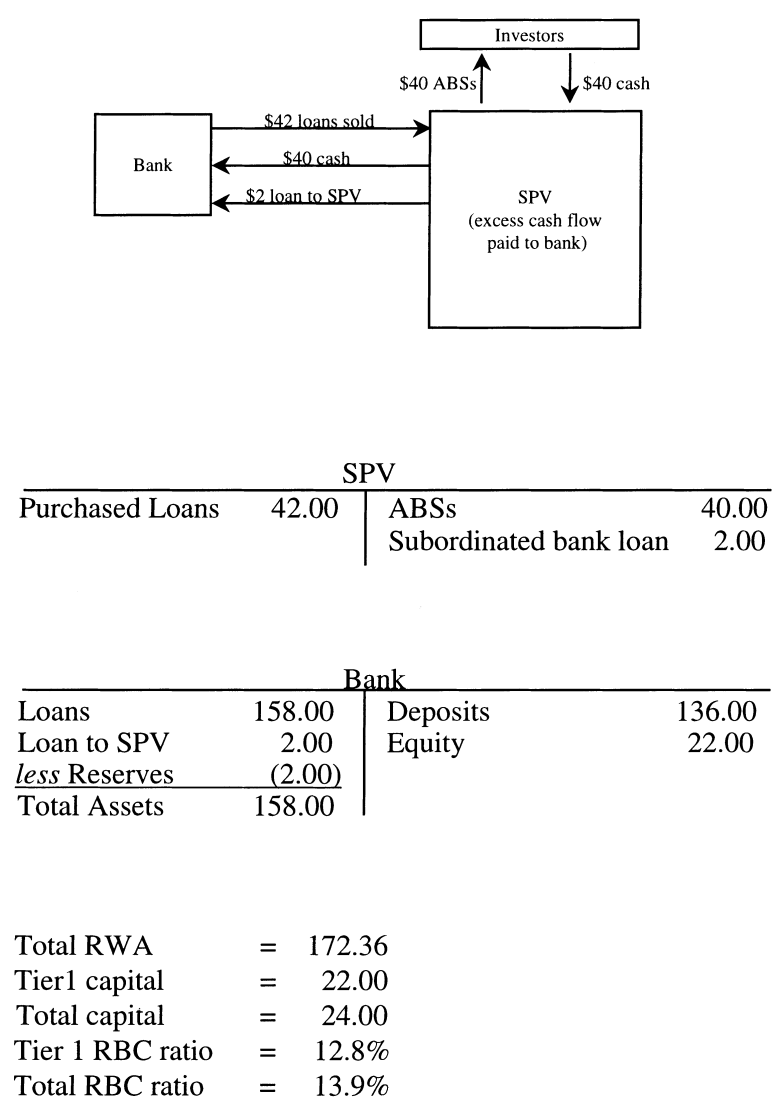

Fig. 3. Securitization of term loans with recourse.

credit risk to the ABS investors, the loan securitization increases (from the base case in Fig. 1) the bank's tier 1 and total $\mathrm{RBC}$ ratios to $12.8 \%$ and $13.9 \%$. In effect, these increases are achieved by "concentrating" the credit risk of the securitized loans into another financial instrument (the subordinated bank loan to the SPV) having a MPCL that is much smaller than that associated with the underlying securitized loans - US\$2.00 compared with US\$42. Although the subordinated loan is treated as recourse and receives an effective $100 \% \mathrm{RBC}$ requirement, the bank's RBC ratios nevertheless increase, provided the amount of recourse per dollar of securitized assets is less than $8 \%$. Since the required direct credit enhancement demanded by the rating agencies will tend to be inversely related to the quality of the underlying securitized assets, this example illustrates how the Accord encourages bank to securitized their highest quality assets. 


\section{A.4. Securitization of revolvers with recourse}

Fig. 4 illustrates the securitization of draw-downs under revolving credit facilities (e.g., credit cards or revolving business lines of credit), which are among the fastest growing forms of RCA. In these arrangements, a bank "designates" certain lines of credit to the SPV. All draw-downs under the designated credit lines are required to be "sold" to the SPV. The SPV, in turn, funds these purchases by issuing, in this example, (a) ABSs in the amount of US\$40 to investors, and (b) a para passu seller's interest (for the residual amount) to the sponsoring bank. Thus, if draw-downs under the designated credit lines equaled US $\$ 100$, the investors' interest would amount to a $40 \%$ share in these loans. (Under current GAAP, the US\$60 sellers' interest generally would be reported as "loans" by the sponsoring bank.)

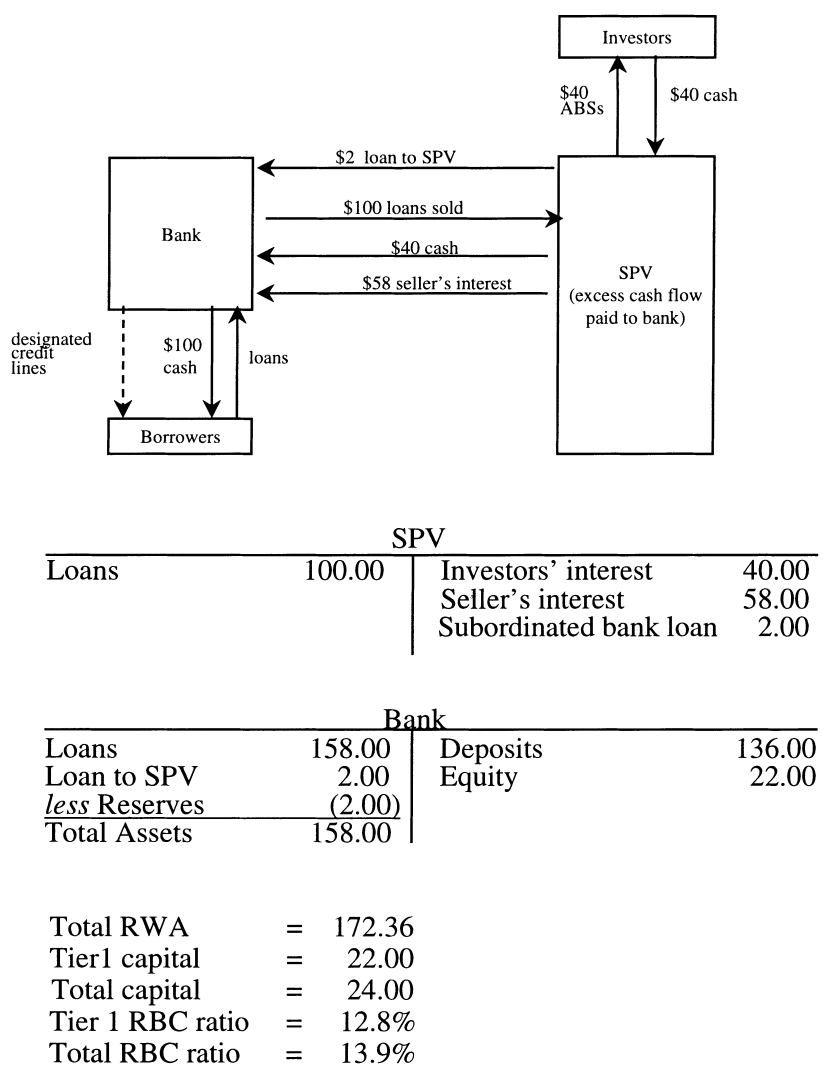

Fig. 4. Securitization of revolvers with recourse. 
Importantly, the seller's interest is not directly subordinated to the investors' interest. That is, the sponsoring bank is entitled to its pro rata shares of principal and interest payments received by the SPV on the underlying loans, ${ }^{11}$ and is required to absorb only its pro rata share of any credit losses (i.e., charge-offs) on the loan pool. Principal and interest payments on the securitized loans that are not allocated to the sellers' interest are available to support the SPV's obligations to the ABS investors. Ordinarily, the investors' share of principal payments would be reinvested by the SPV in new loans.

Under this structure, the sponsoring bank generally would provide sufficient credit enhancements to obtain investment-grade ratings on the ABSs - again implying that little credit risk is actually transferred to the ABS investors. In the exhibit, the bank is assumed to provide two forms of credit enhancement similar to those provided in the preceding example: subordination of the excess servicing to the ABS investors, and a separate US\$2 subordinated investment in the SPV, booked as a loan.

For financial accounting and RBC purposes, the results of this securitization are similar to the securitization of term loans discussed above. That is, even though the subordinated loan is treated as recourse and the bank sheds little credit risk, both the bank's tier 1 and total $\mathrm{RBC}$ ratios increase, provided the amount of recourse per dollar of securitized assets is less than $8 \%$.

\section{A.5. Remote-origination}

More sophisticated methods of RCA can reduce the amount of equity capital that is freed up through securitization programs. One increasingly common technique involves altering the structure of the program so that direct credit enhancements provided by the sponsoring bank are treated as direct credit substitutes, rather than recourse, thereby reducing the bank's total RBC requirement from $100 \%$ to $8 \%$ of the credit enhancement's MPCL. This is achieved by having the SPV, rather than the bank itself, originate the underlying securitized assets (a process termed "remote-origination"). Since the securitized assets will not have been owned or sold by the bank, any credit enhancement provided by the bank to the ABS investors (such as subordinated loan or investment in the SPV) are treated as recourse.

Virtually all ABCPs are structured as remote-origination vehicles. Fig. 5 illustrates the structure of a hypothetical ABCP that invests in loans originated by the SPV. In this example, the direct credit enhancement provided by the bank is again assumed to take the form of a subordinated loan to the SPV.

\footnotetext{
${ }^{11}$ If interest payments on the securitized loans allocated to support the investors' interest (less the investors pro rata share of charge-offs) exceeds the amount due on the ABSs, this surplus is treated as excess servicing and is returned to the sponsoring bank.
} 


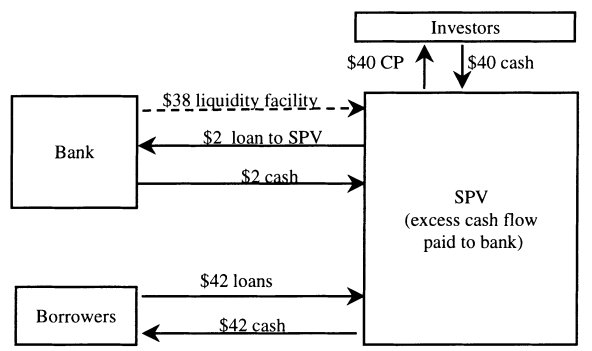

\begin{tabular}{ll|lr}
\multicolumn{4}{c}{ SPV } \\
\hline Loans & 42.00 & CP & 40.00 \\
(Originated by SPV) & & Subordinated bank loan & 2.00
\end{tabular}

\begin{tabular}{lc|lr}
\multicolumn{4}{c}{ Bank } \\
\hline Loans & 158.00 & Deposits & 136.00 \\
Loan to SPV & 2.00 & Equity & 22.00 \\
less Reserves & $(2.00)$ & & \\
Total Assets & 158.00 & &
\end{tabular}

$\begin{array}{llr}\text { Total RWA } & = & 160.00 \\ \text { Tier1 capital } & = & 22.00 \\ \text { Total capital } & = & 24.00 \\ \text { Tier 1 RBC ratio } & = & 13.8 \% \\ \text { Total RBC ratio } & = & 15.0 \%\end{array}$

Fig. 5. Remote-origination vehicles: Loan-backed ABCP.

Note that through the remote-origination and securitization of commercial loans, a sponsoring bank generally can increase its reported capital ratios beyond those achievable by securitizing loans from its own balance sheet, even though the overall risk implications for the bank are essentially the same in both cases.

\section{References}

Baer, H.L., Pavel, C.A., 1988. Does regulation drive innovation? Federal Reserve Bank of Chicago Economic Perspectives 12 (2), pp. 3-15.

Berger, A.N., Udell, G.F., 1993. Securitization, risk, and the liquidity problem in banking. In: Klausner M., White L. (Eds.), Structural Change in Banking, Irwin, Homewood, IL, pp. 227291. 
Carlstrom, C.T., Samolyk, K.A., 1995. Loan sales as a response to market-based capital constraints. Journal of Banking and Finance 19, 627-646.

Chhikara, R.K., Hanson, S.D., 1993. Competitive pricing of farmer Mac's mortgage-backed securities and its future viability: A contingent claims analysis approach. Review of Agricultural Economics 15 (3), 547-566.

Cumming, C., 1987. The economics of securitization, Federal Reserve Bank of New York Quarterly Review 12 (3), 11-23.

DeMarzo, P., Duffie, D., 1999. A liquidity-based model of security design. Econometrica 67, 65-99.

Donahoo, K.K, Shaffer, S., 1991. Capital requirements and the securitization decision. Quarterly Review of Economics and Business 31 (4), 12-23.

Giddy, I., 1985. Regulation and off-balance sheet banking. In: The Search for Financial Stability: The Past Fifty Years, Federal Reserve Bank of San Francisco, pp. 165-177.

Gorton, G.B., Pennacchi, G.G., 1995. Banks and loan sales: Marketing non-markable assets. Journal of Monetary Economics 35, 389-411.

International Swap Dealers Association, 1998. Credit risk and economic capital.

Jagtiani, J., Saunders, A., Udell, G, 1995. The effect of bank capital requirements on bank offbalance sheet financial innovations. Journal of Banking and Finance 19, 647-658.

James, C., 1988. The use of loan sales and standby letters of credit by commercial banks. Journal of Monetary Economics 22, 395-422.

Koppenhaver, G.D., 1989. The effects of regulation on bank participation in the guarantee market. In: Kaufman G. (Ed.), Research in Financial Services: Private and Public Policy, vol 1, JAI Press, Greenwich, CT, pp. 165-180.

Merton, R.C., 1995. Financial innovation and the management and regulation of financial institutions. Journal of Banking and Finance 19, 461-481.

Passmore, W., 1992. Can retail depositories fund mortgages profitably? Journal of Housing Research 3 (2), 305-340.

Pavel, C.A., Phillis D., 1987. Why commercial banks sell loans: An empirical analysis. Economic Perspectives, Federal Reserve Bank of Chicago, July/August, pp. 3-14.

Pennacchi, G.G., 1988. Loan sales and the cost of bank capital. The Journal of Finance XLIII, pp. 375-396.

Picer, S., Dierdorff, M.D., 1997. Understanding structured liquidity facilities in asset-backed commercial paper programs. Asset-Backed Commercial Paper Market Review, First Quarter, Moody's Investors Service, pp. 1-6. 